\title{
An Assessment of Critical Factors Affecting Quality Performance of Government Financed Construction Projects: Evidence from Tanzania
}

\author{
Gwahula Raphael \\ Department of Accounting and Finance, The Open University of Tanzania, P.O. Box \\ 23409, Dar Es Salaam, Tanzania
}

Tel: 255-022-266-7450Ｅ-mail: gwahulagr@gmail.com

Augustine Wittonde Phillip

Regional Manager TANROADS, P.O. Box 62, Shinyanga, Tanzania

Tel: 255-076-983-9382Ｅ-mail:pwittonde@yahoo.co.uk

Received: Sept. 12, 2016 Accepted: September 16, 2016 Published: December 3, 2016

doi:10.5296/bms.v7i2.10014 URL: http://dx.doi.org/10.5296/bms.v7i2.10014

\begin{abstract}
The study objective was "An assessment of critical factors affecting quality performance of government financed construction projects in Tanzania". The study was initiated as much of government financed construction projects are executed with variations on delivering time, cost and quality. The study identified factors if not considered can lead to poor quality performance of projects. Closed end questionnaire consisting of 20 performance factors were issued to 80 respondents dealing with construction related activities, they were required to rank them on a 5 point Likert scale. Data analysis was done using Statistical Package for Social Sciences version 16 (SPSS). The findings revealed that the critical factors that have direct impact on quality performance of government financed construction projects are; project financing processes, experience of contractors in construction industry, project technology, availability of plant and equipment, procurement system and processes as well as the project manager knowledge and skills. A multiple regression model developed showed a positive linear relationship between project quality performance and the critical quality
\end{abstract}




\section{Macrothink}

Business Management and Strategy ISSN 2157-6068 2016, Vol. 7, No. 2

performance factors. All the critical quality performance factors had positive coefficients with an acceptable level of significance. The study recommends further studies on the economic and social factors that hinder women participation in construction relation activities and how training and learning opportunities for continuous improvement will have positive impact on the performance of construction projects.

Keywords: Project performance, Quality performance factors, Contractor's challenges, Government projects, Construction projects 


\section{Introduction}

A number of government financed construction projects have failed to successfully achieve quality performance as provided in the project technical specifications. Many projects had been closed either without achieving the quality requirements or completed with variations to the original quality requirements (URT, 2010). The factors affecting quality performance of government financed construction projects in Tanzania had not been adequately investigated. The general observation had been due to lack of qualified technical personnel for design and supervision of works, lack of competent, experienced and qualified contractors, and lack of appropriate equipment and availability of adequate funds. This paper presents an assessment of critical quality performance factors that if not adequately considered can lead to relatively unacceptable quality performance of projects, and in particular a case of Tanzania.

\section{Literature Review}

Project quality performance or as widely viewed by many scholar as project success had been extensively studied by many researchers who came up with different definition of project success. Project Management Institute Guide Book (2004), argues that the success of projects had been measured through timely delivery, on cost and targeted quality parameters.

The quality performance has developed from the Dark Age period (Rose, 2005), where the craftsmen were responsible for the quality of item. The craftsmen were responsible for design, tools, sales and customers feedback. Quality performance of items depended on craftsmen's skills which kept on improving through repetition of crafting similar products. Taylor (1919), following increased demand of products noted deviations from the perfect products. To improve performance, (he/she?) theorized that it was the responsibility of the management to determine the process for crafting particular item. Craftsmen were only required to follow the methods. The success performance shifted focus from the craftsmen to the process. The Contemporary theories of quality performances focus on understanding of customer requirements (Atkinson, 1999; Rose, 2005). Customer's requirement establishes the performance goal and is one of the measures for quality performance

Kerzner (1998), noted that the project success in the 1960s was basically measured on technical terms by showing if the product worked or not. In the 1980s' the project success became meeting the three objectives of timely completion, at targeted budget, and at a designed level of quality. The Total Quality Management (TQM) however establishes that the project is considered to be success not only by focusing on the measured time, cost and targeted technical specifications but also by customer acceptance. The three traditional project success performance measures of time, cost and quality are not independent. Other scholars (Chan, 2004; Prabhakar, 2008; Abdullah et al., 2010) have noted that the three traditional project performance measures depend on several other factors such as the nature of the project, location, size, technology, contract type, risks involved, project team, client, contractor etc.

There are a number of previous studies that had tried to establish the list of project success factors that can be applicable to all projects, however researchers (Sadeh et al., 2000; 
Enshanssi et al., 2009; Abdullah et al., 2010), have come to the conclusion that each project have specific needs and hence specific success performance factors. Project success performance could be adequately related to achieving goals and objectives in time and at specified costs as well meeting or exceeding the customers/stakeholders' requirements or expectations.

Despite the large variability in the project success factors, efforts had been made to develop predictive models (Khosravi \& Afshari, 2011; Gwaya et al., 2014), that if only critical factors are considered there could be a specific model that can be used to predict if the project will be or had been successful. Application of such models however has not been widely accepted as the so called critical success factors do keep on changing for different projects. Therefore in view of the above this study was put forward to have an opportunity of determining specific and critical success factors affecting quality performance of construction projects being executed in Tanzania.

\section{Research Methodology}

The study focused on identifying the critical factors that hinder quality performance of government financed construction project in Tanzania. Basing on literature review and field discussions with experienced practitioners in constructions industry a list of 20 quality performance factors was established. The primary data were collected from target groups of engineers, contractors and employers working in construction projects. The stratified sampling method was used to identify a group of participants from the population and thereafter a simple sampling approach was applied while issuing questionnaires to respondents.

Close-ended questionnaire consisting of 20 quality performance factors were issued to 80 respondents involved in construction related activities, they were required to rank them on a 5 point Likert scale ranging from; not critical (1), somehow critical (2), critical (3), very critical (4) and extremely critical (5). The quality performance factors that considered were those which could have influence on quality performance of construction projects.

Data collected were analyzed using the Statistical Package for Social Sciences (SPSS) version 16. The method was chosen because it has been widely used in the previous studies. The Kendall's tau correlation coefficients were applied to confirm data agreements for engineers, contractors and employers. Moreover in reference to the empirical literature review, the study considered an existence of a linear relationship between the project quality performance (dependent variable) and the critical factors (independent variables). The relationship assumed to be in the form of a multiple linear model. Collected data were tested on concurrence with the assumptions that underpin the multiple linear regression models. Finally the model itself was developed.

\section{Research Findings}

The collected data were tested for validity and reliability. Validity refers to how well the test 
measures what was purported to be measured. Reliability is the measure of homogeneity in the test results. Reliability in data was tested by use of Cronbach's Alpha. Validity of data, was assured by use of closed end questionnaires. The Cronbach's Alpha obtained was 0.888 . Nunnaly (1978) noted that reliability of $0.7-0.8$ is acceptable for basic social sciences studies. Hence the collected data were considered to be reliable.

\subsection{Descriptive Statistics}

The SPSS tool was used to determine the age, education and experience of respondents participated in the study. The age was divided into three groups; being 20 to 30 years (15\%), 31 to 40 years (34\%) and above 40 years $(51 \%)$. Majority of the respondents were aged above 40 years. This could be attributed by long period of training required for engineers. Indeed construction business requires large amount of capital, hence only few young people ventures to establish themselves as contractors.

The level of education was checked to determine the suitability of individuals involved in responding to the questionnaires. Data analysis shows that only $6 \%$ of participants had a secondary education, $69 \%$ were diploma or degree holders while $25 \%$ had more than a degree qualification. Most of the participants were suitably qualified for the study as had adequate knowledge to understand the questionnaires and to respond accordingly.

Experience in construction industry is the key qualifications for someone to be in a better position to identify key issues that could have major impact of quality performance of the projects. Participants with less than 10 years' experience were $50 \%, 11$ to 20 years were $23 \%$, and those of more than 20 years' experience were $27 \%$. In other words $50 \%$ of participants had adequate experience (over 10 years) in construction industry. Finally analysis showed that, $64 \%$ of participants were projects supervising engineers, $21 \%$ were contractors and $15 \%$ are employers. Enshassi et al. (2009) considered a similar group of experts comprising of experienced owners, project consultants and contractors. Therefore the selected participants for this study were rated to be appropriate.

\subsection{Participants Views on Factors Affecting Quality Performance of Projects}

Applying the SPSS tool, the mean score of each quality performance factor was determined. Table 1 presents the analyzed data on ranking of factors investigated in the study. The table shows that the minimum mean rank score for quality success factors was 2.950 being above the midpoint of 2.5. Cheung and Yeung (1998), commented that any score above the midpoint of the 5 points Likert scale is considered to be important. Hence all the factors considered in this study were rated to be important.

Table 1. Respondents views on factors affecting quality performance of projects

\begin{tabular}{|c|c|c|c|c|c|}
\hline S/No & $\begin{array}{c}\text { Factors affecting quality } \\
\text { performance of government } \\
\text { construction projects }\end{array}$ & Valid & Missing & $\begin{array}{c}\text { Mean } \\
\text { score }\end{array}$ & $\begin{array}{c}\text { Std } \\
\text { Deviation }\end{array}$ \\
\hline
\end{tabular}




\begin{tabular}{|l|l|r|r|r|r|}
\hline 1 & Project financing processes & 79 & 1 & 4.317 & 0.708 \\
\hline 2 & Contractor's experiences in industry & 80 & 0 & 3.900 & 0.773 \\
\hline 3 & $\begin{array}{l}\text { Availability of construction } \\
\text { equipment and spare parts }\end{array}$ & 80 & 0 & 3.850 & 0.901 \\
\hline 4 & Project's technology requirements & 80 & 0 & 3.575 & 0.883 \\
\hline 5 & Procurement system and processes & 80 & 1 & 3.532 & 0.985 \\
\hline 6 & Availability of construction materials & 80 & 0 & 3.525 & 1.055 \\
\hline 7 & $\begin{array}{l}\text { Project managers skills and } \\
\text { knowledge, }\end{array}$ & 80 & 1 & 3.519 & 1.108 \\
\hline 8 & Explicit project planning and design & 80 & 0 & 3.490 & 0.994 \\
\hline 9 & Explicit technical specifications & 80 & 0 & 3.450 & 1.135 \\
\hline 10 & Supervision team skills and & 80 & 0 & 3.400 & 1.165 \\
\hline 11 & knowledge & & & & \\
\hline 12 & Eroject team members' performance & 80 & 0 & 3.375 & 0.998 \\
\hline 13 & Contractor's profitability & 80 & 1 & 3.177 & 1.308 \\
\hline 14 & Decision making process by clients & 80 & 2 & 3.000 & 1.151 \\
\hline 15 & Explicit contract documentation & 80 & 1 & 3.063 & 1.202 \\
\hline 16 & Health and safety issues & 80 & 0 & 3.050 & 1.311 \\
\hline 17 & Variation in climate conditions & 80 & 0 & 2.963 & 1.174 \\
\hline 18 & Local community involvement & 80 & 0 & 2.950 & 1.231 \\
\hline
\end{tabular}

Source: Primary data.

The participants views indicate that where the financing processes of the project is clear from its commencement, the project will be executed smoothly. Garbharran et al. (2012), had similar observations on the four $\mathrm{COMs}$ of project performance. Project financing arrangements refers to "Commitment" from the government or the project financier. Commitment tends to build sense of collectivism among project participants that lead to optimal performance of team members.

The other highly ranked quality performance factors were contractor's experiences in construction industry, availability of construction equipment and spare parts, projects technology's requirements, availability of construction materials and project managers' skills and knowledge. All these factors constitute a "Competence" critical success factor as previously noted by Garbharran et al. (2012). Competence refers to project participants have adequate skills and experience, capable of utilizing up to-date technology for equipment, materials and the project itself.

Similar findings by Mahona (2008), confirms that Project success depended on the technical knowledge of participants, who must be capable of utilizing up to-date technology for equipment, materials and the project itself as noted in this study. 
Moreover the analysis gave the standard deviation of the respondent's view on quality performance factor ranking. The first five (5) highly ranked factors their standard deviation was less than one (1.0). This implies lower data dispersion hence; there is relatively good agreement between participants.

The SPSS tool was also used to determine if individual groups of experts (supervising engineers, contractors and employers) would have similar ranking of the quality performance factors. A group of supervising engineers indicated that the five (5) highly ranked quality performance factors (with their mean score in brackets) were; Project financing processes (4.3), Contractor's experiences in construction industry (3.8), Availability of construction equipment and spare parts (3.7), Explicit project planning and design (3.5), Explicit technical specifications (3.4). The five (5) highly ranked performance factors for supervising engineers include the explicitly technical specifications (ranked fifth) which do not appear in the top five of the ranking by all participants.

Contractor's top five ranking included project's technology requirements and project manager's skills and knowledge. Employer's ranking was similar to that of supervising engineers for first top 5 performance factors. Employers however ranked in the $6^{\text {th }}$ place; the involvement of local community (mean score 3.4) factor for assurance of quality performance of projects. Employers in this study were mainly local councils. This ranking was not surprising as employers, mostly are involved in community based projects, hence no wonder consider involvement of local community is of significant importance. The quality successful project must bring about benefits to the community.

\subsection{Groups Views' Correlations on Quality Performance Factors}

Further study was made on the relationship between the views of different groups of supervising engineers, contractors and employers. The Null hypothesis $\left(\mathrm{H}_{0}\right)$ tested was that "there is no significant association between the views of different groups of experts in regard to the relative importance of the quality performance factors". The Alternative hypothesis $\left(\mathrm{H}_{1}\right)$ is "there is significant association between the views of different groups of experts in regard to the relative importance of the quality performance factors". Statistically, the strength of the association can be proved by determining the correlation between the mean scores from the three groups of experts. A non-parametric correlation test applied was the Kendall's tau correlation coefficient. The Kendall's tau ranges between -1 to +1 for negative and positive correlations respectively. Shown in Table 2 below are the Kendall's correlation coefficients between the three groups of experts.

Table 2. Kendall's tau Correlation Coefficient matrix

\begin{tabular}{|c|l|r|r|r|r|}
\hline \multicolumn{2}{|c|}{ Mean score } & \multicolumn{1}{c|}{$\begin{array}{c}\text { All } \\
\text { respondents }\end{array}$} & \multicolumn{1}{c|}{ Engineers } & \multicolumn{1}{c|}{ Contractors } & \multicolumn{1}{c|}{ Employers } \\
\hline \multirow{2}{*}{$\begin{array}{c}\text { All } \\
\text { respondents }\end{array}$} & Coefficient & 1 & 0.776 & 0.771 & 0.629 \\
\cline { 2 - 6 } & Sig.(2-tailed) & & $0.000^{* *}$ & $0.000^{* *}$ & $0.000^{* *}$ \\
\hline
\end{tabular}




\section{Macrothink}

\begin{tabular}{|c|c|c|c|c|c|}
\hline \multirow[t]{2}{*}{ Engineers } & Coefficient & 0.776 & 1 & 0.615 & 0.461 \\
\hline & Sig.(2-tailed) & $0.000 * *$ & & $0.001 * *$ & $0.010 * *$ \\
\hline \multirow[t]{2}{*}{ Contractors } & Coefficient & 0.771 & 0.615 & 1 & 0.410 \\
\hline & Sig.(2-tailed) & $0.000 * *$ & $0.001 * *$ & . & $0.021 *$ \\
\hline \multirow[t]{2}{*}{ Employers } & Coefficient & 0.629 & 0.461 & 0.410 & 1 \\
\hline & Sig.(2-tailed) & $0.000 * *$ & $0.010 * *$ & $0.021 *$ & \\
\hline Factors & $\mathrm{N}$ & 18 & 18 & 18 & 18 \\
\hline
\end{tabular}

Table 2 shows that the mean scores for various quality performance factors from the three groups of experts are correlated. The highest correlation noted between the mean scores of all respondents and the mean scores of engineers (0.776), and the lowest correlation was between the mean scores of contractors and the mean scores of employers $(0.410)$.

The Null Hypothesis $\left(\mathrm{H}_{0}\right)$ that "there is no significant association between the views of different groups of experts in regard to the relative importance of the quality performance factors" was rejected. There is a strong association among the experts opinion on factors considered to be important in ensuring quality performance of government financed construction projects. Bland (1986) argues that agreement in measuring techniques for two or more variables can be mistakenly related to the correlation between the variables. High correlation coefficient does not necessarily mean strong agreement between the methods or the data being investigated. To verify agreement in views of individual groups a Kruskal Wallis test was selected. Under this test data are ranked by ordering them from lowest to highest and assigning them, in order, the integer values from 1 to the sample size.

Plichta \& Garzon (2009), show that the Kruskal Walli's test is calculated as per equation;

$$
I=\left(\frac{12}{N(N+1)} \sum_{j=1}^{k} \frac{R_{j}{ }^{2}}{n_{j}}\right)-3(N+1)
$$

Where, $\mathrm{H}$ is the Kruskal Walli's test, $\mathrm{k}$ is the number of comparison groups, $\mathrm{N}$ is the total sample size, $n_{j}$ is the sample size in the $\mathrm{j}^{\text {th }}$ group and $\mathrm{R}_{\mathrm{j}}$ is the sum of the ranks in the $\mathrm{j}^{\text {th }}$ group.

The Null Hypothesis $\left(\mathrm{H}_{\mathrm{o}}\right)$ was "there is no significant difference between the mean scores from the group of experts" while the Alternative hypothesis $\left(\mathrm{H}_{1}\right)$ was "there is a significant difference between the mean scores from the groups of experts". The decision rule is stated as "If the calculated value of the Kruskal-Wallis test is less than the critical chi-square value, then the null hypothesis cannot be rejected meaning that the sample comes from the same population".

Data in this study comprised of four groups, $\mathrm{k}$ value equals 4 (mean scores for all respondents, engineers, contractors and employers) at alpha equals 0.01 and the degree of freedom was 3 . The total sample size was 72 and each group had 18 mean scores for each independent 
quality performance factor. Table 3 shows the results obtained.

Table 3. Kruskal Walli's test data

\begin{tabular}{|l|r|}
\hline \multicolumn{1}{|c|}{ Data Description } & \multicolumn{2}{c|}{ Values obtained } \\
\hline Total sample size $(\mathrm{N})$ & 72 \\
\hline Sample size in each group $(\mathrm{n})$ & 18 \\
\hline Kruskal-Wallis value calculated & 9.4361 \\
\hline Chi-square critical & 11.3449 \\
\hline $\mathrm{p}-$ value & 0.02402 \\
\hline
\end{tabular}

From Table 3 the calculated Kruskal Walli's value (9.436) is less than the Chi Square critical value (11.345). Hence the Null hypothesis cannot be rejected. Statistically the results signify the mean scores for all four groups are strongly in agreement.

\subsection{The Critical Quality Performance Factors Affecting Projects}

Having confirmed significant correlations and agreement on respondents' views in regard to the quality performance factors affecting government financed construction projects, the study was undertaken to identify 10 critical factors. In each group, ten (10) quality performance factors with high mean scores were selected and compared. The task was to determine which ones are relatively important in comparison to others. As established by Enshassi et al. (2009), the relevant perception importance factors from each group were determined using the Relative Importance Index method calculated as;

$$
\mathrm{RII}=\left(\sum \mathrm{W}\right) / \mathrm{A} \times \mathrm{N}
$$

Where $\mathrm{W}$ is the score given by a participant in a particular group of experts, $\mathrm{A}$ is the highest score equals to 5 and $\mathrm{N}$ is the number of participants in that particular group of experts. The higher the value of RII the greater importance of the performance factor considered. The relative importance index as presented by equation 2 , could give misleading perceptions on the importance of performance factors. The Relative Importance Index is mostly influenced by the number of participants in that particular group. Measured variables from groups with fewer members may be unnecessarily given higher weighting factors and influence views of respondents where the sample sizes from different groups vary substantially.

Paule and Mandel (1982) show that the variance of the weighted average is minimized when the individual weights are taken as the inverse of the variance of the individual measured values, that is,

$$
\mathrm{w}_{\mathrm{i}}=1 / \operatorname{Var}\left(\mathrm{Y}_{\mathrm{i}}\right)
$$

Where $\mathrm{w}_{\mathrm{i}}$ is the weighting factor for measurement $\mathrm{Y}_{\mathrm{i}}$ and $\mathrm{Y}_{\mathrm{i}}$ is the measured variable. Low weights are given to variable with high variance. The variance measures the level of disparity in views of respondents. Determination of weighting factor in this study adopted both procedures presented by Enshassi et al. (2009) and that by Paule \& Mandel (1982). The two 
formulas were combined to give the modified formulae for a weighting factor as shown below;

$$
\mathrm{W}_{\mathrm{i}}=1 / k A\left(\sum_{1}^{k} M s i /\left(s i^{2}\right)\right.
$$

Where, $W i$ is a weighting factor for group $\mathrm{i}, M s i$ is the mean score for group of experts, $\mathrm{s}_{i}$ is the standard deviation in a particular group of expert, $A$ is the maximum score equals to 5 and $k$ is the number of groups of experts under investigation.

The ratio " $1 / k A^{m}$ in equation 4 above is basically constant and was added in the equation to normalize the weighting factor so that it can become a value with no units.

The mean scores for a particular quality performance factor as assessed by all respondents given in Table 1 above were multiplied by the weighting factor obtained as per equation 4 above. The results are presented for only six most highly ranked factors in Table 4 below.

Table 4. Weighted Mean score for various performance factors

\begin{tabular}{|c|c|c|c|c|}
\hline S/No & $\begin{array}{l}\text { Factors affecting quality } \\
\text { performance of projects }\end{array}$ & $\begin{array}{l}\text { Mean score } \\
\text { for all } \\
\text { respondents }\end{array}$ & $\begin{array}{l}\text { Weighting } \\
\text { factor }\end{array}$ & $\begin{array}{l}\text { Weighted } \\
\text { Mean score }\end{array}$ \\
\hline 1 & Project financing processes & 4.317 & 2.132 & 9.205 \\
\hline 2 & $\begin{array}{l}\text { Contractor's experiences in } \\
\text { construction industry }\end{array}$ & 3.900 & 1.584 & 6.176 \\
\hline 3 & $\begin{array}{l}\text { Availability of construction } \\
\text { equipment and spare parts }\end{array}$ & 3.850 & 1.152 & 4.435 \\
\hline 4 & Project's technology requirements & 3.575 & 1.858 & 6.643 \\
\hline 5 & Procurement system and processes & 3.532 & 1.030 & 3.637 \\
\hline 6 & $\begin{array}{l}\text { Project managers skills and } \\
\text { knowledge, (head of supervision } \\
\text { team) }\end{array}$ & 3.519 & 1.044 & 3.674 \\
\hline
\end{tabular}

The six (6) quality performance factors were considered to be critical and important in improving quality performance of government financed construction projects in Tanzania. The quality performance factors whose weighted mean score became less than 2.5 were viewed as less important. Although such quality performance factors could have attained a 
mean score of above 2.5 of the 5 point Likert scale, but the level of disparity in opinions among respondents was higher making such performance factors less significant.

\subsection{Relationship between Quality Performance and Critical Factors}

Test data were investigated if there could be an empirical mathematical model that could predict quality performance at given critical factors. The assumption is that there could be a linear relationship between the quality performance (dependent variable) and the critical performance factors (independent variables). Analysis was made to determine if the observed critical quality performance factors are related to the project performance.

The identified critical factors were; (i) project financing processes, (ii) contractor's experiences in construction industry, (iii) project's technology requirements, (iv) availability of construction equipment and spare parts, (v) procurement system and processes and (vi) project manager's skills and knowledge. These factors were observed to have a critical and direct impact on quality performance of the project.

The six critical quality performance factors were used in the analysis to determine if there exists a linear relationship between project quality performance (dependent variable) and the critical quality performance factors (independent variables). Prior to further analysis, the test data were checked if they agree with assumptions that underline the multiple linear regression models of linearity, autocorrelation, multicollinearity, homoscedasticity and normality of error distribution between dependent and independent variables.

Having tested and confirmed the assumptions of multiple linear regression models, the study data were used to develop the multiple linear regression model of the following form;

$$
P Q P=\beta_{0}+\beta_{1} P F+\beta_{2} C E+\beta_{3} P T+\beta_{4} P E+\beta_{5} P S+\beta_{6} P M+\varepsilon
$$

Whereby $\boldsymbol{\beta}_{\mathbf{0}}$ is the constant term of the model, $\boldsymbol{\beta}_{\mathbf{1}}$ to $\boldsymbol{\beta}_{\mathbf{6}}$ are coefficients of independent variables and $\varepsilon$ is the error term. The terms PQP refers to project quality performance a dependent variable, where as independent variables are PF, CE, PT, PE and PS. The terms PF refers to project financing processes, CE refers to contractors experience in construction industry, PT means project technology requirements, PE refers to availability of plant and equipment, PS means procurement system and processes and finally PM referring to project manager skills and knowledge.

The study conceptualized that; project financing processing and procurement system have impact on time performance of projects. Availability of plant and equipment as well as the project manager's knowledge and skills were considered to have impact on the cost performance of the project. Finally the contractors experience in construction industry and project technology requirements were considered to have impact on quality target of the project.

The multiple linear regression model shown as equation 5 above was run by use of SPSS tool 
whereby the project quality performance variable (PQP) was regressed against the six critical quality performance factors. The performance factor of project manager skills and knowledge (PM) was considered as a dummy variable coded as 0 or 1 . At planning stage of the project, needs for the project manager skills are relatively less important in comparison to the other factors. At this stage the project manager skills factor was coded as zero (0). During project implementation however, skills for the project manager are far important hence the project manager skills factor in the model was coded as one (1).

4.5.1 The Multiple Linear Regression Model Results

Results for the multiple linear regression model discussed above are presented in the tables 5,

Table 5. Regression Coefficient Values

Coefficients a

Model

$\begin{array}{clll}\text { Unstandardized } & \text { Standardize } & \mathrm{t} & \text { Sig. } \\ \text { Coefficients } & \mathrm{d} & & \\ & \text { Coefficients } & & \end{array}$

Beta Std. Beta

Error

(Constant)

$(0.023)$

0.815

$(0.029)$

0.977

Project Financing processes

0.990

0.177

0.202

5.587

0.000

Contractors experience in

1.258

0.161

0.277

7.813

0.000

construction industry

Project technology

1.328

0.149

0.335

8.936

0.000

Availability of plant $\&$

1.162

0.139

0.299

8.357

0.000

equipment

Procurement system

1.236

0.125

0.346

9.916

0.000

Table 5 contains the regression coefficients values. Using the data in Table 5 the project quality performance model can be presented as;

$$
\mathrm{PQP}=-0.023+0.99 \mathrm{PF}+1.258 \mathrm{CE}+1.328 \mathrm{PT}+1.162 \mathrm{PE}+1.236 \mathrm{PS}
$$

The first data for un-standardized coefficients is the multiple linear regression constant $(-0.023)$ with an error of 0.815 and a p-value of 0.977 . The regression coefficient is not 
statistically significant. The constant is the predicted value when all independent factors are set to zero. Frost (2013) observed that this constant is clearly meaningless and one shouldn't even try to give it a meaning. There should be no project quality performance if all quality performance factors are not considered at all. The constant term serves as a tool for any bias that is not accounted for by the terms in the model. The role of the regression model is to minimize residuals between the observed and predicted data.

The other un-standardized data are the coefficients to the regression model. The coefficient for project financing processes is 0.99 with a p-value of 0.000 , coefficient for contractors experience in construction industry is 1.258 with a $\mathrm{p}$-value of 0.000 , coefficient for project technology requirement is 1.328 with a p-value of 0.000 coefficient for availability of plant and equipment is 1.162 with a p-value of 0.000 , and the coefficient for procurement system and processes is 1.236 with a p-value of 0.000 . All coefficients are statistically significant. The model was considered to be statistically significant.

\section{Discussion of Results}

\subsection{Critical Factors That Hinder Quality Performance of Project}

The specific objective was to identify critical factors that hinder quality performance of government financed construction project in Tanzania. Close-ended questionnaires were used to obtain responses from individuals involved in planning, supervision and execution of government financed construction projects. Based on their responses the study revealed that, there are six (6) critical factors that had a direct influence on the quality performance of government financed construction projects in Tanzania. The identified six (6) critical factors are discussed hereunder as follows;

\section{a) Project Financing Processes}

The project financing processes was the highly ranked quality performance factor among all respondents. The study finding is similar to Corner (1996), who noted that project financing processes involve generating finance on a limited recourse for the purposes of developing a large capital-intensive project. Project financing processes is important in all stages of projects from initiation, planning, execution and commissioning. Moreover, Chan (2001) supports the finding and shows that lack of sustained financing processes led to project unit cost variations, time variation, project net present values variability, changes in project functionality and stakeholders dissatisfaction. Definitely this is failure to achieve the quality initially planned. Other scholars (Frimpong, 2003; Aibimi, 2006; Ramanathan et al., 2012) are also in agreements with the finding. Lack of project financing arrangement could lead to compromise on quality, project delays and legal disputes due to delays of payments to the contractor, cost overruns, etc.

b) Contractors experience in construction industry

Contractors experience in construction industry was the second highly ranked quality performance factors. Respondents observed that contractor's experience plays a very 
important role in achieving quality performance of the projects. Contractors experience combines both experience of its staff and outstanding involvement of the firm in construction projects.

The Tanzanian Construction Industry Policy (2003) supports the findings and emphasizes on the need of having experienced contractors in construction projects. Lack of experienced contractors in the government construction projects is one of the challenges put forward by the policy. The policy directs the government to develop capabilities of local contractors through training, allocating more work opportunities and resources in terms of finance. Study by Matiko (2007), as well is in agreement with these findings as it shows that elements of quality project output include; workmanship, teamwork, cost control, timely project completion, proper resource management, availability of experienced and skilled personnel, competitive tendering and continuous improvement. All these elements can be managed and properly controlled by experienced contractors.

Furthermore Atout (2008), Ntuli \& Allopi (2014) support these findings and comment that the success of construction projects depended on the experience of the contractor and capability of the contractor's project manager. The project manager manages and directs the project, based on a full understanding of the requirements and the vision. Inadequate experience and skills for contractors led to; lack of understanding tendering process and procurement policies, lack of knowledge to develop business plans, inability for regular securing of work, lack of operational and managerial skills amongst contractors, underpricing and lack of understanding of the general conditions of contracts. Basing on the finding it can be argued that contracting arrangement that includes selection of experienced contractors plays an important role in successful execution of a project.

c) Project Technology requirements,

Respondents ranked third the project technology requirement. The respondents' view emphasized on the need of having appropriate knowledge and skills on the work, associated tools, equipment and materials. The recent construction technology variations particularly for materials required in building projects have become an important parameters for customer's satisfaction and hence quality performance of the project. Lack of clear understanding of the technological requirement at early stage of the project may lead to variations hence increased project costs and delays.

Other scholars (Sadeh et al., 2000; Prajogo \& Sohal, 2006; Otim \& Alinaitwe, 2013)) had similar findings and show that the technological uncertainty dimension played a significant role in project success. The level of technology involvement determines the risks contained in the project and hence its success. Moreover integration of TQM and technology could result into improved process management and customer focus capabilities. Indeed project characteristics being complexity, size, construction design and material type seriously affected performance of construction projects. These characteristics which form part of project technology requirements have influence on project quality performance. 
d) Availability of plant and equipment for construction projects

The fourth highly ranked quality performance factor was the availability of plant and equipment for construction works. This factor was mostly ranked higher by contractors. These are the one involved in actual execution of construction projects.

Most of government financed construction projects being executed in Tanzania are on roads. No one envisages quality road works in the absence of specific plant and equipment. Findings by other scholars (Odeh \& Battainesh, 2002; Sambasivan \& Soon, 2007) are in agreement with the results that plant and equipment availability was the key cause of project delays. Availability of plant and equipment plays a major role in ensuring that projects are executed on schedule, at targeted budget and within an acceptable quality.

Currently contractors have realized the importance of construction plant and equipment; hence are trying to acquire and own fleet of plant and equipment. It is not always possible for the contractor to own each and every type of construction equipment required for the project. Chinchore \& Khare (2014) have similar findings and observed that contractors need training on factors that affect selection of appropriate plant and equipment for works. Selection should depend on the utility of particular plant and equipment, the contractor has to economically justify whether to purchase the equipment or to hire it.

e) Procurement Systems and Processes

Procurement system as a project quality performance factor ranked fifth. Respondent underscored that for quality performance of projects there is a need of having a well-recognized procurement system. Policy makers, financiers, planners and designers should be aware of the procurement system to be used in acquiring an entity that will be responsible for execution of the project well from instigation of the project.

Noor et al. (2013, is in agreement with finding as procurement category offers a lot of influence on successful project outcome. The procurement category can be traditional that involve design, bid and build (DBB) while the non-tradition ones are the build operate own (BOO) and build operate and transfer (BOT). The DBB is the common method of procurement in use for most construction projects in Tanzania. The DBB has the advantages of being easy to use, least cost, provides fair amount of competition, provides adequate time to review design, has higher degree of quality certainty and promotes transparence.

f) Project manager knowledge and skills (head of supervision team)

The quality performance factor, project manager knowledge and skills ranked six in the study. The study referred to the project manager as the head of the project supervision team. Respondents considered that such person should have adequate knowledge, skills and experience in the project. Project manager manages project data and people. As a leader must be able to establish direction for the future, communicate the project data and forge an aligned team work spirit. 
Scholars (Faridi, 2006; Le Hoal et al., 2007; Bantley, 2007; Mallewo, 2014)) are in agreement with the findings and they noted that poor site management and supervision were the major reasons for project delays. Poor site management and supervision could be attributed to lack of leadership skills or managerial capability of the project manager. The scholars urged that project managers should have outstanding technical skills and interpersonal skills.

\subsection{Project Quality Performance and Critical Performance Factors Relationship}

The study also examined the relationship between quality performance and the critical quality performance factors that affect performance of government financed construction project in Tanzania. A model (equation 6 under section 4.5.1) showing positive linear relationship between the independent variable and the dependent variable was developed. Khosravi \& Afshari (2011) and Gwaya et al. (2014) had similar finding on the linear relationship between project success and various performance factors.

The positive linear relationship in the model implies that agencies overseeing government construction projects should put in place strategies for ensuring the critical performance factors are well thought-out at project planning stage. Quality successfulness of government construction projects could be assured once these factors are made to be the focal points by all financiers, employers, planners and all other stakeholders involved in project planning, execution, commissioning and maintenance.

\section{Conclusion and Recommendations}

The main objective of this study was an assessment of critical factors affecting quality performance of government financed construction projects: a case of Tanzania. The study findings have established that quality performance of government financed construction projects in Tanzania is influenced by six critical quality performance factors namely; project financing processes, experience of contractors in construction industry, project technology, availability of plant and equipment, procurement system and processes as well as the project manager knowledge and skills.

Further to the above it was also established that there is a positive multiple linear relationship between critical quality performance factor and the quality performance of government financed construction projects in Tanzania.

The study findings show that quality performance of construction projects could be achieved if issues discussed in the study are well thought at the project initiation. Ignoring these issues renders difficulties in attaining targeted quality of construction works. The study has provided a tool to policy makers and planners who wish to engage into new construction projects. The critical factors for quality performance, forms an important knowledge base for achieving quality performance in construction projects. The traditional project success factors of time, cost and schedule can no longer stand alone; they strongly need to be amplified by the findings discussed in this report.

Finally during discussions of the findings it was noted that further studies are required to 
assess the economic and social factors that hinders women participation in construction relation activities, and how training and learning opportunities for continuous improvement if will have positive impact on performance of construction projects.

\section{Acknowledgement}

The authors wish to appreciate the great value of the intellectual guidance, valuable comments, patience and constructive criticisms received from the management of The Open University of Tanzania. Special thanks also goes to all engineers, contractors and employers who participated in this study for their timely response to questionnaires issued to them and for apportioning time for face to face discussions during working hours hence disturbing their working schedules.

\section{References}

Abdullah, A. A., Rahman, H. A., Harun Z., Alashwal, M. A., \& Beksin, A. M. (2010). Literature mapping, a bird's eye view on classification of factors influencing project success. African Journal of Business Management, 4(19), 4174 - 4182.

Aibimi, A. A., \& Odeyinka, A. (2006). Construction delays and their causative factors in Nigeria. Journal of Construction Engineering Management, 132(7), 667-677.

Atkinson, R. (1999). Project Management: Cost, Time and Quality, Two Best Guesses and A Phenomenon, It's Time to Accept Other Success Criteria. International Journal of Project Management, 1999, 17(6),

Atout, M. (2008). The obligation of the contractor's project managers in projects; World of Engineering.

Brantley, W. (2007). Five secrets of project success. University of Villanova.

Chan, A. P. C. (2001). Framework for measuring success in construction projects. Queensland University of Technology: Australia.

Chan, A. P. C., \& Chan, A. P. L. (2004). Key performance indicators for measuring construction success Benchmarking. International Journal, 11(2), 203-221.

Chan, T. K., \& Theong, M. C. (2013). A review of the Performance of the Malaysian Construction Industry. Proceeding Construction in Developing Countries (CIB); World Building Congress Construction and Society, Brisbane Australia.

Cheung, S., \& Yeung, Y. (1998). The effectiveness of the dispute resolution advisor construction success, Benchmarking. International Journal of Project Management, 16(16), 367-374.

Chrischore, N. D., \& Khane, P. (2014). Planning and Section of Heavy Construction Equipment in Civil Engineering and Applications. International Journal for Engineering Research, 4(1), ISSN 2248 - 9622. 
Construction Industry Policy (2003). United Republic of Tanzania, Ministry of Works.

Corner, B. (196). Teaching note. The Wharton School. Retrieved from http:/finance.wharton.upenn.edu/-bodnarg/ml/projfinance.pd

Dissanayaka, S. M., \& Kumaraswamy, M. M (1999). Evaluation of factors affecting time system: a critical appraisal. International Journal of Project Management, 16(6), 367-374.

Enshassi, A., Mohamed, S., \& Abushaban, S. (2009). Factors Affecting the Performance of Construction Projects in the Gaza Strip. Journal of Civil Engineering and Management, 15(3), 269-280. http://dx.doi.org/10.3846/1392-3730.2009.15.269-280

Faridi, A.S. \& El-Sayegh, S.M. (2006). Significant factors causing delay in the UAE construction industry. Journal of Construction Management and Economics, 24(11), 1167-1176. http://dx.doi.org/10.1080/01446190600827033

Frimpong, Y., Oluwoye, J., \& Crawford, L. (2003). Causes of delay and cost overruns in construction of groundwater projects in a developing countries, Ghana as a case study. International Journal of Project Management, 21, 321-326. http://dx.doi.org/10.1016/S0263-7863(02)00055-8

Frost, J. (2013). What are the effect of Multi collinearity and when can I avoid or ignore them? The Min lab Blog.

Garbharran, H., Govender, J., \& Msani, T. (2012). Critical success factors influencing project success in the construction industry. Oorsigartikels Review articles Acta Structilia, 19(2).

Garcia, S., Molina D., Lozano, M., \& Herrera, F. (2008). A study on the use of non-parametric tests for analyzing the evolutionary algorithms behaviour; Case study on the CEC 2005, Special Session on real parameter optimization.

Gwaya, A. O., Masu, S. M., \& Oyawa, W. O. (2014). Development of a Benchmarking Model for Construction; Projects in Kenya. International Journal of Soft Computing and Engineering (IJSCE), ISSN: 2231-2307, 4(5).

Kerzner, H. (1998). In Search of Excellence in Project Management. Van Nostrand Reinhold, New York, NY.

Khosravi, S., \& Afshari, H. (2011). A Success Measurement Model for Construction Projects. International Conference on Financial Management and Economics, IPEDR vol.11, IACSIT Press, Singapore.

Le-Hoai, L., Lee, Y. D., \& Lee, J. Y. (2008). Delay and Cost Overruns in Vietnam Large Construction Projects: A comparison with other selected countries. KSCE Journal of Civil Engineering, 367-377. http://dx.doi.org/10.1007/s12205-008-0367-7

MacDonald, J. H. (2009). Handbook of Biological Statistics. University of Delaware. Sparky House Publishing: Baltimore, Maryland. 
Mahona, S. G. (2008). An Assessment of Factors Affecting Implementation of Community Based Construction Projects in Tanzania: A Case of PEDP and SEDP. Thesis for the Master of Engineering Management, University of Dar es Salaam.

Mallewo, A. (2014). An assessment of project management concepts in building projects in Tanzania, a case study of building projects in Dar es Salaam. Unpublished (Master of Science degree on construction economy and management), Ardhi University, Tanzania.

Matiko, S. (2007). Critical Performance Improvement Factors for Contractors in Tanzania; CIB $2007-375$.

Muguiyi, M. W. (2012). Factors Influencing Performance of Contractors of Government-Funded Building Projects in Kirinyaga County, Kenya. A Research Project Report Submitted In Partial Fulfilment of the Award of a Master of Arts Degree in Project Planning and Management, University of Nairobi.

Noor, M., Rahmani, F., Alshanbri, N., Malik, M. A., \& Khalfan, T. M. (2013). Perception of Procurement on Successful Infrastructure Project Outcomes in Pakistan. Construction and Project Management: RMIT University.

Ntuli, B., \& Allopi, D. (2014). Impact of inadequate experience and skills on construction sector in Kwa Zulu Natal, South Africa. Engineering, Technology and Applied Science Research, 4(1), 570 - 575.

Nunnally, J. C., \& Bernstein, I. H. (1994). Psychometric theory (3rd ed.), New York McGraw-Hill.

Odeh, A. M., \& Battaineh, H. T. (2002). Causes of construction delay: traditional contracts. $\begin{array}{llll}\text { International Journal of Project Management, } & \text { 20, }\end{array}$ http://dx.doi.org/10.1016/S0263-7863(00)00037-5

Otim, G., \& Alinaitiwe, H. M. (2013). Factors affecting performance of paved roads construction projects in Uganda. Unpublished report by School of Built Environment / College of engineering, Design Arts and technology, Makerere, Uganda.

Paule, R. C., \& Mandel, J. (1982). Consensus Values on Weighting Factors. Journal of Research on the National Bureau of Standards, 87(5).

Prabhakar, G. P. (2008). What is project success: A literature review. International Journal of Business and management, 3(9), 3-10. http://dx.doi.org/10.5539/ijbm.v3n9p3

Prajogo, D. I., \& Sohal, A. S. (2006). The integration of TQM and technology/R\&D management in determining quality and innovation performance. International Journal of Management Science, Omega 34, 296 -312. http://dx.doi.org/10.1016/j.omega.2004.11.004

Project Management Institute. (2004). A Guide to the Project Management Body of Knowledge, Third Edition. Newtown Square: PA. 


\section{Macrothink}

Business Management and Strategy

ISSN 2157-6068

2016, Vol. 7, No. 2

Ramanathan, C., Narayanan, S. P. \& Idrus, A. B. (2012). Construction delays causing risks on time and cost a critical review. Australasian Journal of Construction Economics and Building, 2, 27 -57. http://dx.doi.org/10.5130/ajceb.v12i1.2330

Rashid, R. A., Taib, I. M., Ahmad, W. B., Ali A.W., \& Zainordin, Z. M. (2006). Effect of procurement system on performance of construction projects. Department of Quantity Surveying, Faculty of Built Environments University of Malaysia.

Rose, K. H. (2005). Project Quality Management: Why, What, How? J. Ross Publishing.

Sadeh, A., Divr, D., \& Shenhar, A. (2000). The role of contract types in the success of R \& D defense projects under increasing uncertainty. Project Management Journal January 2000. $31(3), 14-22$.

Sambasivan, M., \& Soon, Y. W. (2007). Causes and effects of delays in Malaysian construction industry. International Journal of Project Management, 25, 517-526. http://dx.doi.org/10.1016/j.ijproman.2006.11.007

Takim, R., Akintoye, A., \& Kelly, J. (2002). Analysis of performance measurement of construction Projects in Malaysia. School of Built and Natural Environment, Glasgow Caledonian University, City Campus: Glasgow G4 OBA, UK.

United Republic of Tanzania (2010). The Performance Audit Report on Road works. Ministry of Finance: Tanzania.

\section{Copyright Disclaimer}

Copyright for this article is retained by the author(s), with first publication rights granted to the journal. This is an open-access article distributed under the terms and conditions of the Creative Commons Attribution license (http://creativecommons.org/licenses/by/3.0/). 